\title{
The effect of casein phosphopeptides on calcium absorption from calcium-fortified milk in growing rats
}

\author{
H. Tsuchita*, T. Suzuki, and T. Kuwata \\ Nutritional Science Research Institute, Meiji Milk Products Co. Ltd, 1-21-3 Sakaecho, Higashimurayama, \\ Tokyo 189-8530, Japan \\ (Received 3 November 1999 - Revised 5 June 2000 - Accepted 16 June 2000)
}

\begin{abstract}
The effect of casein phosphopeptides (CPP) prepared from bovine casein by enzymatic hydrolysis (extrinsic CPP) on Ca absorption from Ca-fortified milk was studied in young male rats, in comparison with that produced from casein in the small intestine (intrinsic CPP). The gastrointestinal $\mathrm{Ca}$ disappearance $(\mathrm{Ca}$ ingested - (gastric $\mathrm{Ca}+$ intestinal $\mathrm{Ca})$ ) was calculated as an indirect measurement of $\mathrm{Ca}$ absorption. After being fasted overnight, the animals were given $2.0 \mathrm{ml} \mathrm{Ca}$-fortified milk (30 g fat, $35 \mathrm{~g}$ protein, $2.7 \mathrm{~g} \mathrm{Ca} / \mathrm{kg}$ ) without or with $1.0 \mathrm{mg}$ extrinsic $\mathrm{CPP} / \mathrm{ml}$, by gastric intubation. The intestinal soluble Ca level after $15 \mathrm{~min}$ and the gastrointestinal $\mathrm{Ca}$ disappearance after 15 and $30 \mathrm{~min}$ in the rats given Ca-fortified milk with $1.0 \mathrm{mg}$ extrinsic $\mathrm{CPP} / \mathrm{ml}$ were significantly higher than these figures in the rats given Cafortified milk without CPP $(P<0 \cdot 05)$. When the rats were given unfortified milk $(1.35 \mathrm{~g} \mathrm{Ca} /$ $\mathrm{kg}$ ) in another reference experiment, no significant effect on intestinal soluble $\mathrm{Ca}$ and gastrointestinal $\mathrm{Ca}$ disappearance was apparent from the addition of CPP to milk. Ca availability was estimated by measuring ${ }^{45} \mathrm{Ca}$-deposits in the bones of rats $48 \mathrm{~h}$ after being given $2.0 \mathrm{ml} \mathrm{Ca}-$ fortified milk labelled with ${ }^{45} \mathrm{Ca}(180 \mathrm{kBq} / 2 \mathrm{ml})$ with or without $0.25 \mathrm{mg} \mathrm{CPP} / \mathrm{ml}$. The levels of ${ }^{45} \mathrm{Ca}$ radioactivity of the femur and tibia from the rats given Ca-fortified milk with extrinsic CPP were significantly higher than those from the control group $(P<0.05)$. These results suggest that the addition of CPP to Ca-fortified milk could increase $\mathrm{Ca}$ absorption by growing rats mainly from $\mathrm{CaCO}_{3}$ added to the milk. The mechanism of $\mathrm{CPP}$ related to the interaction of $\mathrm{CPP}$ and $\mathrm{Ca}$ in the gastrointestinal tract is discussed.
\end{abstract}

Calcium absorption: Casein phosphopeptide: Milk

Dairy foods are the main source of $\mathrm{Ca}$ in the diet. Milk and milk products are well known for their good $\mathrm{Ca}$ availability in man: (Recker \& Heaney, 1985; Recker et al. 1988) and in experimental animals (Wong \& LaCroix, 1980; Buchowski \& Miller, 1990). The good availability of $\mathrm{Ca}$ from milk could partly reflect the enhancing effect of lactose (Miller, 1989) and casein phosphopeptides (CPP) on $\mathrm{Ca}$ absorption. In addition, colloidal $\mathrm{Ca}$ and the $\mathrm{Ca}: \mathrm{P}$ ratio may be involved in the good $\mathrm{Ca}$ availability from milk. Dairy product manufacturers are now marketing highCa milk in response to the increased publicity of this mineral (Tunick, 1987). In this case, an enhancing effect of lactose or CPP in Ca-fortified milk on $\mathrm{Ca}$ absorption could be expected. However, the contribution of these components to the $\mathrm{Ca}$ availability of $\mathrm{Ca}$-fortified milk has not been clarified.
When rats were fed with a bovine-casein diet, $\mathrm{Ca}$ absorption was enhanced due to CPP derived from digestion of the protein (intrinsic CPP; Naito et al., 1972; Naito \& Suzuki, 1974). Feeding CPP prepared from bovine casein by enzymatic hydrolysis (extrinsic CPP) has also shown an enhancing effect on $\mathrm{Ca}$ absorption by animals (Lee et al. 1992; Tsuchita et al. 1993). The effect of extrinsic $\mathrm{CPP}$ on $\mathrm{Ca}$ absorption could reflect the $\mathrm{Ca}-$ solubilizing action which inhibits the formation of insoluble calcium phosphate in the intestine (Sato et al. 1986). However, some reports have not shown such an effect of extrinsic CPP on Ca absorption (Brommage et al. 1991; Yuan \& Kitts, 1991). This discrepancy might have originated from differences in the experimental design such as the dietary $\mathrm{Ca}$ level or the $\mathrm{Ca}$ status of the animals. In addition, the extent to which the interaction between

\footnotetext{
Abbreviation: CPP, casein phosphopeptides.

* Corresponding author: Dr H. Tsuchita, fax +81 42395 1829, email hiroshi_tsuchita@meiji-milk.com
} 
extrinsic $\mathrm{CPP}$ and $\mathrm{Ca}$ occurs in the gastrointestinal tract may be a key factor for this inconsistency. Since the physico-chemical state of $\mathrm{Ca}$ in fluid milk is not homogenous (Holt, 1985), different interactions between CPP and the mineral during the digestion of Ca-fortified milk and unfortified milk may occur. In this context, the interaction between extrinsic CPP and $\mathrm{Ca}$ should be clarified in both the small intestine and in the stomach. The aim of this present study is to evaluate the effect of extrinsic CPP on Ca absorption from Ca-fortified milk and unfortified milk in growing male rats, focusing on the difference in the effects of intrinsic CPP and extrinsic CPP. We conducted experiments to: (1) clarify the Ca-solubilizing effect of extrinsic CPP in the stomach as well as in the intestine; (2) assess the level of extrinsic CPP; and (3) estimate the effect of extrinsic CPP on $\mathrm{Ca}$ availability.

\section{Materials and methods}

\section{Milk preparation}

Milk samples were prepared by dissolving skimmed-milk powder in recombined milk made from skimmed milk and cream (30 g milk fat, $35 \mathrm{~g}$ milk protein and $52 \mathrm{~g}$ lactose/ $\mathrm{kg}$ ). $\mathrm{Ca}$ and/or CPP was added or not according to the experimental protocols (Table 1). A colloidal solution of $\mathrm{CaCO}_{3}$ was stabilized by adding gum arabic before mixing with milk. The concentration of gum arabic in the milk was $0 \cdot 1 \mathrm{mg} / \mathrm{ml}$. CPP was dispersed with skimmed-milk powder and dissolved in milk. CPP was a commercial product prepared from a tryptic hydrolysate of bovine whole casein (CPP-III; Meiji Seika Kaisha, Ltd, Tokyo, Japan), whose content of phosphopeptides was estimated to be $860 \mathrm{~g} / \mathrm{kg}$ DM by an HPLC analysis (Saito et al. 1998) and the N:P ratio was $8 \cdot 0$. The content of $\mathrm{Ca}$ in each milk sample was as follows: unfortified milk $1.35 \mathrm{mg} / \mathrm{ml}$, Ca-fortified milk $2.7 \mathrm{mg} / \mathrm{ml}$ (Table 1). The samples of milk used in Experiment 4 were prepared by adding $50 \mu{ }^{45} \mathrm{CaCl}_{2}$ in water (specific activity $36 \mathrm{kBq} / \mu \mathrm{l}$, Ca content $55 \mathrm{ng} / \mu \mathrm{l}$; NEM Life Science Products, Inc., Boston, MA, USA) to $20.0 \mathrm{ml} \mathrm{Ca}$-fortified milk with or without CPP, the solution being held overnight whilst being continuously stirred at $10^{\circ} \mathrm{C}$.

\section{Animals}

Male Sprague-Dawley rats (6-week-old; Japan SLC, Shizuoka, Japan) were housed in individual Al cages in a temperature-controlled $\left(23 \pm 2^{\circ} \mathrm{C}\right)$ room with $50 \pm 10 \%$ humidity and a 12 hour light-dark cycle, and were fed on a stock diet (CE-7; Clea Japan, Tokyo, Japan) for a $10 \mathrm{~d}$ adaptation period. The composition of the stock diet was as follows: Ca $1050 \mathrm{mg} / \mathrm{kg}, \quad \mathrm{P} 930 \mathrm{mg} / \mathrm{kg}$, crude protein $176 \mathrm{~g} / \mathrm{kg}$. The care of the rats in this study conformed with Guide for the Care and Use of Laboratory Animals (National Research Council, 1985).

\section{Experimental procedures}

Four experiments were carried out: Experiment 1 and 2 were performed to clarify the Ca-solubilizing effect of extrinsic CPP in Ca-fortified milk or unfortified milk; Experiment 3, to assess the effect of the level of extrinsic $\mathrm{CPP}$ on $\mathrm{Ca}$ absorption; and Experiment 4, to evaluate the effect of extrinsic CPP on Ca availability by using ${ }^{45} \mathrm{Ca}$.

Experiment 1. After being fasted overnight $(11 \pm 2 \mathrm{~h})$, sixty-three rats were assigned to two groups of twenty-eight animals each and to one group of seven animals, each group having a similar mean body weight of 217 (SD 3.1) g. One group of twenty-eight animals was given $2.0 \mathrm{ml} \mathrm{Ca-}$ fortified milk with added CPP $(1.0 \mathrm{mg} / \mathrm{ml})$ by gastric intubation. At times of 15, 30, 60 and 120 min after the administration, seven animals were chosen at random to measure the $\mathrm{Ca}$ concentration in their gastrointestinal contents. The other group of twenty-eight animals was given $2.0 \mathrm{ml} \mathrm{Ca-fortified} \mathrm{milk} \mathrm{without} \mathrm{CPP} \mathrm{orally,} \mathrm{and}$ treated similarly. A group of seven animals was not given anything and was treated similarly to act as a control group. Animals randomly chosen at each time were anaesthetized by inhalation of isoflurane $\left(1.5-3.5 \%\right.$ in a mixture of $\mathrm{O}_{2}-$ $\left.\mathrm{CO}_{2}(95: 5, \mathrm{v} / \mathrm{v})\right)$. An incision was made in the abdomen, and the cardia, pylorus and ileocaecum were ligated. The stomach and small intestine were excised, and the contents were recovered by flushing the interior with $5.0 \mathrm{ml}$ distilled deionized water.

Experiment 2. Another batch of sixty-three rats was subjected to the same procedure as that in Experiment 1, except that the milk samples were not fortified with $\mathrm{CaCO}_{3}$ (unfortified milk).

Experiment 3. Four groups of fourteen rats each were given $2.0 \mathrm{ml} \mathrm{Ca-fortified} \mathrm{milk} \mathrm{with} \mathrm{different} \mathrm{levels} \mathrm{of} \mathrm{CPP}$ orally (Table 1). After this administration (30 and $60 \mathrm{~min}$ ), seven animals were randomly chosen from each group to measure the $\mathrm{Ca}$ concentration in the gastrointestinal contents.

Experiment 4. Two groups of seven rats each were given orally $2.0 \mathrm{ml}$ of one of the Ca-fortified milk samples labelled with ${ }^{45} \mathrm{Ca}$, to which CPP had been added $(0.25 \mathrm{mg} /$ $\mathrm{ml})$ or not (Table 1). Blood samples $(200 \mu \mathrm{l})$ were taken from the tail vein by making a small incision at 20 and

Table 1. Composition of milk samples

\begin{tabular}{lccc}
\hline Experiment no. & Milk* & CPP $(\mathrm{mg} / \mathrm{ml})$ & Time point $(\mathrm{min}) \dagger$ \\
\hline 1 & Ca-fortified & $0,1.0$ & $15,30,60,120$ \\
2 & Unfortified & $0,1.0$ & $15,30,60,120$ \\
3 & Ca-fortified & $0,0 \cdot 25,0.5,1.0$ & 30,60 \\
4 & Ca-fortified & $0,0 \cdot 25$ & $20,40,60,180,360,540,1440,2040$ \\
\hline CPP, casein phosphopeptides. & & \\
* The Ca content of Ca-fortified milk and unfortified milk was $2.7 \mathrm{mg} / \mathrm{ml}$ and $1.35 \mathrm{mg} / \mathrm{ml}$ respectively. \\
† Time point at which gastrointestinal Ca was measured $(n 7$ at each time point).
\end{tabular}


$40 \mathrm{~min}$ and at $1,3,6,9,24$ and $34 \mathrm{~h}$ after the administration to determine the ${ }^{45} \mathrm{Ca}$ radioactivity. The incision wound was treated with surgical adhesive after the blood sampling. The animals were killed by overdosing with sodium pentobarbital $48 \mathrm{~h}$ after administering the radioisotope, and the right femur and tibia were excised to determine the ${ }^{45} \mathrm{Ca}$ radioactivity.

\section{Analytical methods}

The gastric and intestinal contents were centrifuged (15 $000 \mathrm{~g}, 20 \mathrm{~min}$ ). The precipitate was dried and ashed overnight in a muffle furnace at $600^{\circ} \mathrm{C}$ (insoluble $\mathrm{Ca}$ ). The ashed sample was then dissolved in $1.0 \mathrm{M}-\mathrm{HNO}_{3}$ for $\mathrm{Ca}$ determination by an atomic absorption spectrophotometer (AA-6500F; Shimadzu, Kyoto, Japan), the concentration of $\mathrm{Ca}$ in the supernatant being directly determined by the instrument (soluble $\mathrm{Ca}$ ). The bone samples were digested with a mixture of 15:7 $\mathrm{M}-\mathrm{HNO}_{3}$ (three volumes) and 9.2 M$\mathrm{HClO}_{4}$ (one volume) at $200^{\circ} \mathrm{C}$ for $2 \mathrm{~h}$. The radioactivity of ${ }^{45} \mathrm{Ca}$ in the plasma and digested bone was measured by a liquid scintillation analyser (TRI-CARB 2700TR; Packard Japan, Tokyo, Japan).

\section{Calculation of the calcium variables}

The level of gastric Ca was calculated as the sum of gastric insoluble $\mathrm{Ca}$ and gastric soluble $\mathrm{Ca}$. The gastrointestinal $\mathrm{Ca}$ disappearance was calculated from the amount of $\mathrm{Ca}$ in the gastrointestinal content as follows: gastrointestinal $\mathrm{Ca}$ disappearance $=\mathrm{Ca}$ ingested $-($ gastric $\mathrm{Ca}+$ intestinal $\mathrm{Ca}$ ), where intestinal $\mathrm{Ca}$ is the sum of insoluble $\mathrm{Ca}$ and soluble $\mathrm{Ca}$ in the intestinal contents.

\section{Statistical analysis}

Data reported in the figures and tables are expressed as mean values with their standard errors. In all experiments, one-way ANOVA with a subsequent Bonferroni test was used at each time point to test for any significant differences in the mean values of the experimental groups $(P<0.05)$. Data from Experiments 1,2 and 3 were separately analysed by two-way ANOVA, with CPP addition and time as the main effect. Data from Experiment 4 were analysed by ANOVA for repeated measures. The analysis was performed by using StatView version 4.0 statistical software (Abacus Concepts, Inc., Berkeley, CA, USA).

\section{Results}

\section{Gastric emptying}

In Experiment 1, the gastric $\mathrm{Ca}$ level in the rats given $\mathrm{Ca}$ fortified milk with added CPP was significantly lower than that in the rats given Ca-fortified milk without CPP at the time points of 15 and $30 \mathrm{~min}(P<0.05$; Fig. 1$)$. The addition of CPP to Ca-fortified milk significantly modified the gastric $\mathrm{Ca}$ content $(P<0 \cdot 05)$. The gastric insoluble $\mathrm{Ca}$ level in the rats given Ca-fortified milk with added CPP was significantly lower than that in the rats given

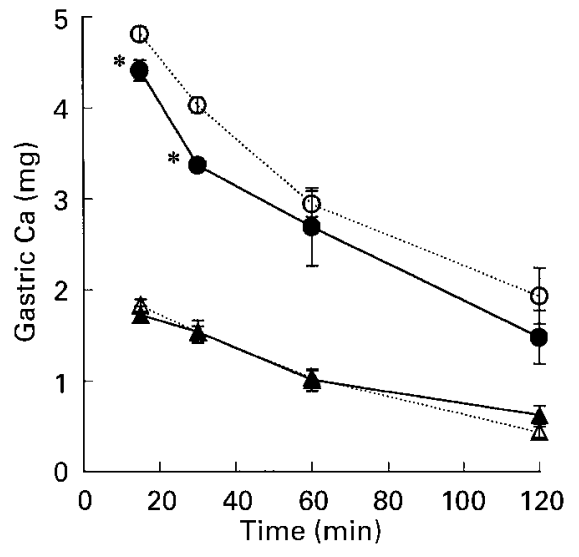

Fig. 1. Total $\mathrm{Ca}$ in the gastric contents from rats given Ca-fortified milk with $1.0 \mathrm{mg}$ casein phosphopeptides (CPP)/ml (๑) or without CPP $(O)$ in Experiment 1 and unfortified milk with $\mathrm{CPP}(\boldsymbol{\Lambda})$ or without $\operatorname{CPP}(\triangle)$ in Experiment 2. For details of composition of milks see Table 1 and p. 6 , and for procedures see p. 6 . Values are means for seven rats per group with their standard errors represented by vertical bars. The values from the rats not given milk were as follows (mg): Experiment 1, 0.130 (SE 0.009); Experiment 2, 0.053 (SE 0.014 ). Mean values were significantly lower than those of the control group at the same time point in Experiment 1: ${ }^{*} P<0.05$. Data were analysed separately in each experiment by two-way ANOVA. In Experiment 1: CPP effect, $P<0.05$; time effect, $P<0.05$; CPP $\times$ time interaction, NS. In Experiment 2: CPP effect, NS; time effect, $P<0.05 ; \mathrm{CPP} \times$ time interaction, NS.

Ca-fortified milk without CPP at the time points of 15 and $30 \min (P<0.05$; data not shown). Since the amount of $\mathrm{Ca}$ ingested by each animal was constant (5.4 mg/animal in Experiment 1 , and $2.7 \mathrm{mg}$ /animal in experiment 2 ), a low level of gastric $\mathrm{Ca}$ indicates a high level of gastric emptying of $\mathrm{Ca}$. In contrast, when the rats were given unfortified milk in Experiment 2, the addition of CPP did not affect the gastric Ca level (Fig. 1).

\section{Intestinal soluble calcium}

The amount of soluble $\mathrm{Ca}$ in the intestinal contents increased with increasing time after the ingestion of the milk samples. Only in Experiment 1 was the intestinal soluble Ca level in the rats given $\mathrm{Ca}$-fortified milk with $\mathrm{CPP}$ significantly higher than that in the rats given Ca-fortified milk without CPP 15 min after the ingestion (Fig. 2). Although a similar trend was apparent at the time points of 30,60 and $120 \mathrm{~min}$, the addition of CPP to Ca-fortified milk did not significantly affect the level of intestinal soluble $\mathrm{Ca}$ (Fig. 2). The intestinal insoluble $\mathrm{Ca}$ level in the rats given $\mathrm{Ca}$-fortified milk with CPP was similar to that in the rats given Ca-fortified milk without CPP 15 and 30 min after the ingestion, but tended to be higher after $60 \mathrm{~min}$ (data not shown). When the rats were given unfortified milk in Experiment 2, the addition of CPP had no significant effect on the amount of soluble $\mathrm{Ca}$ (Fig. 2).

\section{Gastrointestinal calcium disappearance}

The gastrointestinal $\mathrm{Ca}$ disappearance in the rats given $\mathrm{Ca}$ fortified milk with CPP was significantly higher than that in the rats given Ca-fortified milk without CPP 15 and 30 min 


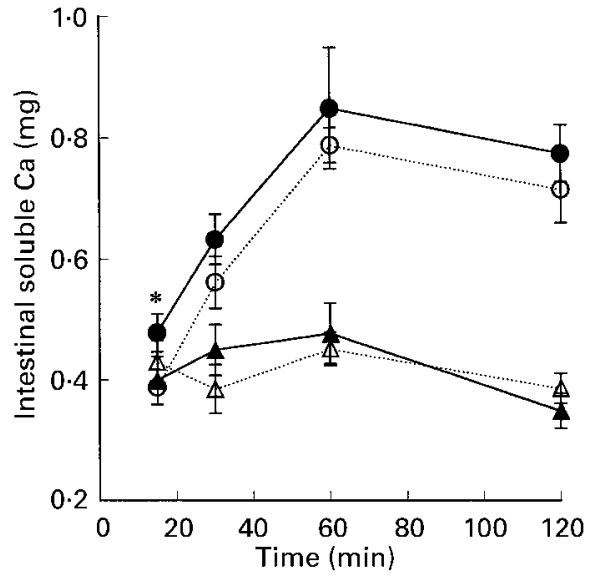

Fig. 2. Soluble $\mathrm{Ca}$ in the small intestinal contents from rats given $\mathrm{Ca}$ fortified milk with $1.0 \mathrm{mg}$ casein phosphopeptides (CPP)/ml $(\bullet)$ or without CPP $(\bigcirc)$ in Experiment 1 and unfortified milk with CPP $(\mathbf{\Lambda})$ or without CPP $(\triangle)$ in Experiment 2. For details of composition of milks see Table 1 and p. 6 , and for procedures see p. 6 . Values are means for seven rats per group with their standard errors represented by vertical bars. The values from the rats not given milk were as follows (mg): Experiment 1, 0.196 (SE 0.017); Experiment 2, 0.159 (SE 0.026 ). Mean value was significantly higher than that of the control group at the same time point in Experiment 1: ${ }^{\star} P<0.05$. Data were analysed separately in each experiment by two-way ANOVA. In Experiment 1: CPP effect, NS; time effect, $P<0.05$; CPP $\times$ time interaction, NS. In Experiment 2: CPP effect, NS; time effect, NS; $\mathrm{CPP} \times$ time interaction, NS.

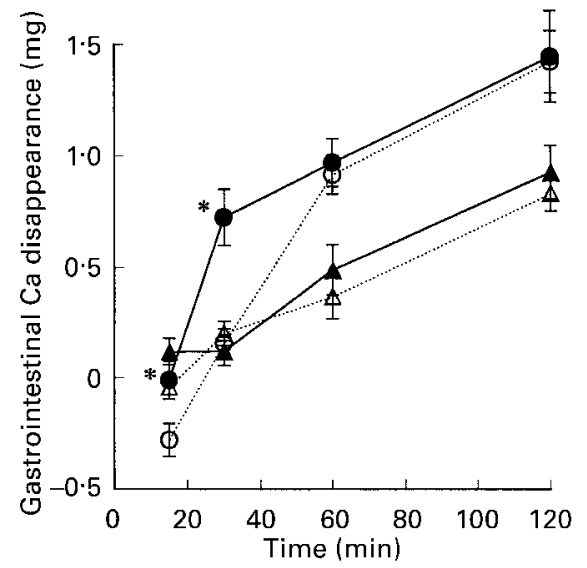

Fig. 3. Gastrointestinal Ca disappearance by rats given Ca-fortified milk with $1.0 \mathrm{mg}$ casein phosphopeptides $(\mathrm{CPP}) / \mathrm{ml}(\bullet)$ or without CPP $(\bigcirc)$ in Experiment 1 and unfortified milk with CPP $(\mathbf{\Lambda})$ or without CPP $(\triangle)$ in Experiment 2. For details of composition of milks see Table 1 and p. 6, and for procedures see p. 6 . Values are means for seven rats per group with their standard errors represented by vertical bars. The values from the rats not given milk were as follows (mg): Experiment 1, -0.427 (SE 0.047); Experiment 2, -0.474 (SE 0.227 ). Mean values were significantly higher than those of the control group at the same time point in Experiment 1: ${ }^{*} P<0.05$. Data were analysed separately in each experiment by two-way ANOVA. In Experiment 1: CPP effect, $P<0.05$; time effect, $P<$ 0.05; CPP $\times$ time interaction, NS. In Experiment 2: CPP effect, NS; time effect, $P<0.05$; CPP $\times$ time interaction, NS.
Table 2. Gastrointestinal calcium disappearance by rats given calcium-fortified milk at $30 \mathrm{~min}$ and $60 \mathrm{~min}$ after ingesting milk* (Mean values with their standard errors for seven rats per group)

\begin{tabular}{|c|c|c|c|c|}
\hline \multirow[b]{3}{*}{ CPP level (mg/ml) } & \multicolumn{4}{|c|}{ Gastrointestinal Ca disappearance (mg) } \\
\hline & \multicolumn{2}{|c|}{$30 \mathrm{~min}$} & \multicolumn{2}{|c|}{$60 \mathrm{~min}$} \\
\hline & Mean & SE & Mean & SE \\
\hline 0 & $-0.254^{a}$ & 0.166 & $0.286^{a}$ & 0.181 \\
\hline 0.25 & $0.242^{\mathrm{b}}$ & 0.085 & $0.788^{b}$ & 0.076 \\
\hline 0.5 & $0.213^{b}$ & 0.071 & $0.692^{b}$ & 0.122 \\
\hline $1 \cdot 0$ & $0.253^{\mathrm{b}}$ & 0.064 & $0.744^{b}$ & 0.080 \\
\hline
\end{tabular}

after the ingestion $(P<0.05$; Fig. 3). The addition of CPP to Ca-fortified milk significantly affected the gastrointestinal $\mathrm{Ca}$ disappearance $(P<0 \cdot 05)$. In contrast, when the rats were given unfortified milk, the addition of CPP had no significant effect on the gastrointestinal $\mathrm{Ca}$ disappearance (Fig. 3).

The gastrointestinal $\mathrm{Ca}$ disappearance in the rats given Ca-fortified milk with $0.25,0.5$ or $1.0 \mathrm{mg} \mathrm{CPP} / \mathrm{ml}$ was significantly higher than that in the animals given this milk without CPP 30 and $60 \mathrm{~min}$ after the ingestion $(P<0.05$; Table 2). However, there was no significant difference related to the level of added CPP among the three groups given samples with CPP addition.

\section{${ }^{45} \mathrm{Ca}$ in the blood and bones}

The radioactivity of plasma ${ }^{45} \mathrm{Ca}$ from the rats given $\mathrm{Ca}$ fortified milk with $0.25 \mathrm{mg} \mathrm{CPP} / \mathrm{ml}$ tended to be slightly higher than that from the animals given milk without CPP 20 and $40 \mathrm{~min}$, and 1, 3 and $6 \mathrm{~h}$ after the ingestion, although there was no statistical significance in the difference (Fig. 4). There was also no significant difference in the area under the curve among the groups (data not shown).

The radioactivity of the femur and tibia from the rats given Ca-fortified milk with CPP was significantly higher than that from the control group $(P<0.05$; Table 3$)$.

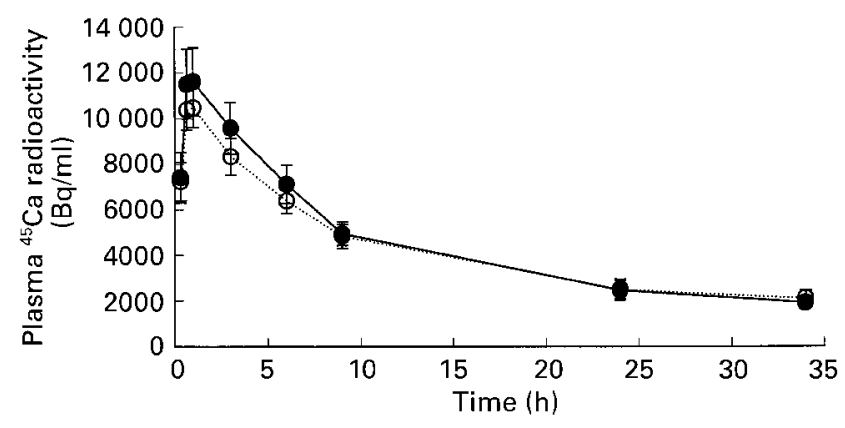

Fig. 4. Plasma ${ }^{45} \mathrm{Ca}$ radioactivity from rats given Ca-fortified milk with $0.25 \mathrm{mg}$ casein phosphopeptides (CPP) $(\bullet)$ or without CPP $(O)$. For details of composition of milks see Table 1 and p. 6, and for procedures see pp. 6-7. Values are means for seven rats per group with their standard errors represented by vertical bars. Data were analysed by two-way ANOVA: CPP effect, NS; time effect, $P<0.05$; CPP $\times$ time interaction, NS. 
Table $3 .{ }^{45} \mathrm{Ca}$ radioactivity in the right femur and tibia from rats given calcium-fortified milk $\dagger$

(Mean values with their standard errors for seven rats per group)

\begin{tabular}{|c|c|c|c|c|}
\hline & \multicolumn{4}{|c|}{${ }^{45} \mathrm{Ca}$ radioactivity $\left(\times 10^{4} \mathrm{~Bq} / \mathrm{g}\right.$ bone $)$} \\
\hline & \multicolumn{2}{|c|}{ Femur } & \multicolumn{2}{|c|}{ Tibia } \\
\hline & Mean & SE & Mean & SE \\
\hline Control & $51 \cdot 7$ & $2 \cdot 5$ & $49 \cdot 6$ & $2 \cdot 6$ \\
\hline CPP $(0.25 \mathrm{mg} / \mathrm{ml})$ & $61 \cdot 8^{*}$ & 3.2 & $60 \cdot 2^{*}$ & $3 \cdot 1$ \\
\hline
\end{tabular}

CPP, casein phosphopeptides.

Mean values were significant different from corresponding control values: ${ }^{\star} P<0.05$.

† For details of composition of milks see Table 1 and p. 6, and for procedure see pp. 6-7

\section{Discussion}

The present data indicate that the addition of CPP to $\mathrm{Ca}$ fortified milk could increase $\mathrm{Ca}$ absorption by young male rats. In contrast, no effect of extrinsic $\mathrm{CPP}$ on $\mathrm{Ca}$ absorption was apparent when the animals were given unfortified milk. This suggests that extrinsic CPP enhanced the $\mathrm{Ca}$ absorption mainly from $\mathrm{CaCO}_{3}$ added to the milk. The gastrointestinal $\mathrm{Ca}$ disappearance was observed at an earlier time after the ingestion of Ca-fortified milk due to the effect of extrinsic CPP: the gastrointestinal $\mathrm{Ca}$ disappearance 15 and $30 \mathrm{~min}$ after the rats had been given Ca-fortified milk with $1.0 \mathrm{mg} \mathrm{CPP} / \mathrm{ml}$ was significantly greater than that after the rats had been given Ca-fortified milk without CPP $(P<0 \cdot 05)$. Although the gastrointestinal $\mathrm{Ca}$ disappearance does not equal the apparent $\mathrm{Ca}$ absorption by metabolic measurement, the higher gastrointestinal $\mathrm{Ca}$ disappearance could have been associated with an increase in $\mathrm{Ca}$ absorption. The radioactivity of ${ }^{45} \mathrm{Ca}$ in the femur and tibia excised $48 \mathrm{~h}$ after the ingestion of milk was significantly higher in the rats given Ca-fortified milk with $0.25 \mathrm{mg} \mathrm{CPP} / \mathrm{ml}$ than in the rats given $\mathrm{Ca}$-fortified milk $(P<0 \cdot 05)$, which indicates increased $\mathrm{Ca}$ availability (Buchowski et al. 1989). The radioactivity of plasma ${ }^{45} \mathrm{Ca}$ in the rats given $\mathrm{Ca}$-fortified milk with $0.25 \mathrm{mg} \mathrm{CPP} / \mathrm{ml}$ was slightly higher than that in the rats given control milk up to $6 \mathrm{~h}$ after the ingestion, but no significant difference could be detected at each time point $(P<0 \cdot 05)$. This might have been caused by low exchangeability of the tracer in Ca-fortified milk. The relative exchangeability of the extrinsic tracer in bovine milk was $70 \%$ (Yamanouchi \& Yoneda, 1977). In addition, half the amount of $\mathrm{Ca}$ in $\mathrm{Ca}$-fortified milk was insoluble $\mathrm{CaCO}_{3}$, which suggests a lower exchangeability. Therefore, the radioactivity of plasma ${ }^{45} \mathrm{Ca}$ was overestimated (Buchowski et al. 1989), and the effect of extrinsic CPP might not have been clearly shown.

Since the gastrointestinal $\mathrm{Ca}$ disappearance was calculated by the amount of $\mathrm{Ca}$ remaining in the gastrointestinal tract, the value included the amount of $\mathrm{Ca}$ that had moved into the caecum. The caecum has been reported as a highly efficient absorptive site (Favus, 1985), and $\mathrm{Ca}$ absorption across the caecum could have physiological importance in regulating intestinal $\mathrm{Ca}$ homeostasis in rats (Karbach \& Feldmeier, 1993). The radioactivity of plasma ${ }^{45} \mathrm{Ca}$ from the rats given $\mathrm{Ca}$-fortified milk with $\mathrm{CPP}$ tended to be higher than that from the rats given control milk up to $6 \mathrm{~h}$ after the ingestion. This suggests that the extrinsic CPP might have remained in the caecum as well as in the small intestine until at least $6 \mathrm{~h}$ after ingesting the milk. The presence of CPP in the caecum is supported by the report that part of the CPP formed in the small intestine was detected in the faeces from rats that had been fed on a casein-based diet (Pelissier et al. 1981; Kasai et al. 1992). Further experiments are needed to elucidate the digestibility of extrinsic CPP and its influence on $\mathrm{Ca}$ absorption in the caecum.

Among many reports on $\mathrm{Ca}$ absorption from dairy products (Smith et al. 1985; Sheikh et al. 1987; Recker et al. 1988; Nickel et al. 1996), there has been little data presented on Ca-fortified milk. In a study using the doublelabel stable isotope technique in human subjects, no clear difference was apparent in the efficiency of $\mathrm{Ca}$ absorption between skimmed milk and Ca-enriched skimmed milk (Fairweather-Tait et al. 1989). In the present study, insoluble $\mathrm{CaCO}_{3}$ was suspended in milk by adding a hydrocolloid to prevent precipitation. When some hydrocolloids were added to milk products, the additives had no effect on the solubility of $\mathrm{Ca}$ after in vitro digestion (Marin $\&$ Zee, 1992). This evidence suggests that hydrocolloids added to Ca-fortified milk would have been unlikely to affect $\mathrm{Ca}$ absorption in the present results.

Approximately one-third of the $\mathrm{Ca}$ in bovine milk is present in the serum phase as free $\mathrm{Ca}^{2+}$ or is predominantly complexed by citrate and phosphate. The remaining twothirds is partly incorporated in micellar calcium phosphate and partly bound directly to casein (Holt, 1985). Such physico-chemical characteristics of $\mathrm{Ca}$ in milk would affect the interaction with CPP. When being digested in the stomach, diffusible or free $\mathrm{Ca}^{2+}$ will be released from unfortified milk as well as $\mathrm{CaCO}_{3}$. However, the gastric $\mathrm{Ca}$ in rats given unfortified milk was not affected by the addition of CPP in Experiment 2. This indicates that there was little interaction between CPP and the Ca released from unfortified milk, especially during the first $60 \mathrm{~min}$ of the experiment. One reason for this would be that CPP added to the milk could be emptied from the stomach faster than $\mathrm{Ca}$ was liberated from milk (Holt \& Hukins, 1991). Alternatively, diffusible $\mathrm{Ca}$ released from unfortified milk might have been emptied from the stomach in a stable matrix with the protein hydrolysate, resulting in no interaction with extrinsic CPP. A mineral-rich peptide fraction including phosphopeptides has been recovered from the tryptic hydrolysate of bovine casein micelles (Gagnaire et al. 1996), although the gastric emptying characteristics were not referred to. The increase in gastric emptying of $\mathrm{Ca}$ by the addition of extrinsic CPP to Ca-fortified milk could have been due to the effect of CPP on increasing soluble $\mathrm{Ca}$ in the stomach. Increasing soluble $\mathrm{Ca}$ is the key mechanism of CPP to augment $\mathrm{Ca}$ absorption from the small intestine. Therefore, it is effective for CPP to move simultaneously with $\mathrm{Ca}$ from the stomach to the small intestine, because the interaction between CPP and Ca would easily take place in the small intestine. When all dietary $\mathrm{Ca}$ was bound to CPP in advance, good $\mathrm{Ca}$ availability has been shown (Tsuchita et al. 1996), where any interference with any interaction between CPP and $\mathrm{Ca}$ from the digestion of other 
food ingredients would have been reduced. It is suggested that the effect of extrinsic CPP on $\mathrm{Ca}$ absorption could depend on the degree of interaction occurring between $\mathrm{Ca}$ and CPP in the stomach as well as in the small intestine.

The present result using growing rats should not be directly extrapolated to man, and dietary intervention studies are needed to evaluate the addition of CPP to Cafortified milk and other milk products. Improvement of the availability of $\mathrm{Ca}$ from milk products may be of help for those people with low Ca absorption (Heaney et al. 1994).

\section{References}

Brommage R, Juillerat MA \& Jost R (1991) Influence of casein phosphopeptides and lactulose on intestinal calcium absorption in adult female rats. Lait 71, 173-180.

Buchowski MS \& Miller DD (1990) Calcium bioavailability from ripening cheddar cheese. Journal of Food Science 55, 12931295, 1364.

Buchowski MS, Sowizral KC, Lengemann FW, Van Campen D \& Miller DD (1989) A comparison of intrinsic and extrinsic tracer methods for estimating calcium bioavailability to rats from dairy foods. Journal of Nutrition. 119, 228-234.

Fairweather-Tait SJ, Johnson A, Eagles J, Ganatra S, Kennedy H \& Gurr MI (1989) Studies on calcium absorption from milk using a double-label stable isotope technique. British Journal of Nutrition 62, 379-388.

Favus MJ (1985) Factors that influence absorption and secretion of calcium in the small intestine and colon. American Journal of Physiology 248, G147-G157.

Gagnaire V, Pierre A, Molle D \& Leonil J (1996) Phosphopeptides interacting with colloidal calcium phosphate isolated by tryptic hydrolysis of bovine casein micelles. Journal of Dairy Research 63, 405-422.

Heaney RP, Saito Y \& Orimo H (1994) Effect of casein phosphopeptide on absorbability of co-ingested calcium in normal postmenopausal women. Journal of Bone and Mineral Metabolism 12, 77-81.

Holt C (1985) The milk salts: Their secretion, concentrations and physical chemistry. In Developments in Dairy Chemistry, pp. 143-181 [PF Fox, editors]. London: Elsevier Applied Science.

Holt C \& Hukins DWL (1991) Structural analysis of the environment of calcium ions in crystalline and amorphous calcium phosphate by X-ray absorption spectroscopy and a hypothesis concerning the biological function of the casein micelle. International Dairy Journal 1, 151-165.

Karbach U \& Feldmeier H (1993) The cecum is the site with the highest calcium absorption in rat intestine. Digestive Diseases and Sciences 38, 1815-1824.

Kasai T, Honda T \& Kiriyama S (1992) Caseinphosphopeptides (CPP) in feces of rats fed casein diet. Bioscience, Biotechnology and Biochemistry 56, 1150-1151.

Lee YS, Park G \& Naito H (1992) Supplemental effect of casein phosphopeptides (CPP) on the calcium balance of growing rats. Journal of Japanese Society of Nutrition and Food Science 45, 333-338.

Marin J \& Zee JA (1992) Influence of hydrocolloids on potential bioavailability of calcium in dairy products. Microbiologie, Aliments, Nutrition 10, 23-28.

Miller DD (1989) Calcium in the diet: Food sources, recommended intakes and nutritional bioavailability. Advances in Food and Nutrition Research 33, 103-156.
Naito H, Kawakami A \& Imamura T (1972) In vivo formation of phosphopeptide with calcium-binding property in the small intestinal tract of the rat fed on casein. Agricultural and Biological Chemistry 36, 409-415.

Naito H \& Suzuki H (1974) Further evidence for the formation in vivo of phosphopeptide in the intestinal lumen from dietary $\beta$ casein. Agricultural and Biological Chemistry 1974, 15431545.

National Research Council (1985) Guide for the Care and Use of Laboratory Animals. Bethesda, MD: National Institutes of Health.

Nickel KP, Martin BR, Smith DL, Smith JB, Miller GD \& Weaver CM (1996) Calcium bioavailability from bovine milk and dairy products in premenopausal women using intrinsic and extrinsic labeling techniques. Journal of Nutrition 126, 14061411.

Pelissier JP, Dubos F \& Daburon F (1981) Search for phosphopeptides in the feces of axenic rats fed radioactive ovine casein. Reproduction, Nutrition, Development 21, 513518.

Recker RR, Bammi A, Barger-Lux MJ \& Heaney RP (1988) Calcium absorbability from milk products, an imitation milk, and calcium carbonate. American Journal of Clinical Nutrition 47, 93-95.

Recker RR \& Heaney RP (1985) The effect of milk supplements on calcium metabolism, bone metabolism and calcium balance. American Journal of Clinical Nutrition 41, 254-263.

Saito Y, Lee YS \& Kimura S (1998) Minimum effective dose of casein phosphopeptides (CPP) for enhancement of calcium absorption in growing rats. International Journal for Vitamin and Nutrition Research 68, 335-340.

Sato R, Noguchi T \& Naito H (1986) Casein phosphopeptide (CPP) enhances calcium absorption from the ligated segment of rat small intestine. Journal of Nutritional Science and Vitaminology 32, 67-76.

Sheikh MS, Santa Ana CA, Nicar MJ, Shiller LR \& Fordtran JS (1987) Gastrointestinal absorption of calcium from milk and calcium salts. New England Journal of Medicine 317, 532-536.

Smith TM, Kolars JC, Savaiano DA \& Levitt MD (1985) Absorption of calcium from milk and yogurt. American Journal of Clinical Nutrition 42, 1197-1200.

Tsuchita H, Goto T, Shimizu T, Yonehara Y \& Kuwata T (1996) Dietary casein phosphopeptides prevent bone loss in aged ovariectomized rats. Journal of Nutrition 126, 86-93.

Tsuchita H, Sekiguchi I, Kuwata T, Igarashi C \& Ezawa I (1993) The effect of casein phosphopeptides on calcium utilization in young ovariectomized rats. Zeitschrift für Ernährungswissenschaft 32, 121-130.

Tunick MH (1987) Calcium in dairy products. Journal of Dairy Science 70, 2429-2438.

Wong NP \& LaCroix DE (1980) Biological availability of calcium in dairy products. Nutrition Reports International $\mathbf{2 1}$, 673-680.

Yamanouchi K \& Yoneda Y (1977) Effect of some treatments of milk on the exchangeability of colloidal calcium in milk with soluble calcium. Agricultural and Biological Chemistry 41, 2395-2399.

Yuan YV \& Kitts DD (1991) Confirmation of calcium absorption and femoral utilization in spontaneously hypertensive rats fed casein phosphopeptide supplemented diets. Nutrition Research 11, 1257-1272. 